\title{
Principles and applications of Ligation Mediated PCR methods for DNA-based typing of microbial organisms*
}

\author{
Beata Krawczyk ${ }^{\circledR}$, Józef Kur ${ }^{1}$, Karolina Stojowska-Swędrzyńska² and Marta Śpibida ${ }^{1}$ \\ 1Department of Molecular Biotechnology and Microbiology, Faculty of Chemistry, Gdańsk University of Technology, Gdańsk, Poland; \\ 2Department of Biochemistry, Faculty of Biology, University of Gdańsk, Gdańsk, Poland
}

\begin{abstract}
A significant number of DNA-based techniques has been introduced into the field of microorganisms' characterization and taxonomy. These genomic fingerprinting methods were developed to detect DNA sequence polymorphisms by using general principles, such as restriction endonuclease analysis, molecular hybridization, and PCR amplification. In recent years, some alternative techniques based on ligation of oligonucleotide adapters before DNA amplification by PCR, known as LigationMediated PCR methods (LM PCR), have been successfully applied for the typing of microorganisms below the species level. These molecular methods include: Amplified Fragment Length Polymorphism (AFLP), Amplification of DNA fragments Surrounding Rare Restriction Sites (ADSRRS), PCR Melting Profiles (PCR MP), Ligation Mediated PCR/Shifter (LM PCR/Shifter), Infrequent-Restriction-Site Amplification (IRS PCR), double digestion Ligation Mediated Suppression PCR (ddLMS PCR). These techniques are now applied more and more often because they involve less time, are comparably inexpensive, and require only standard lab equipment. Here, we present a general review of this group of methods showing their possibilities and limitations. We also identify questions and propose solutions which may be helpful in choosing a particular LM PCR method for the achievement of the required goal.
\end{abstract}

Key words: rapid methods, molecular epidemiology, genotyping, microbial phylogenetics, PCR (polymerase chain reaction)

Received: 23 September, 2015; revised: 25 November, 2015; accepted: 18 December, 2015; available on-line: 17 February, 2016

\section{INTRODUCTION}

Genomic typing focuses on the analysis of DNA of microorganisms at the level of a strain or subspecies, and detects many classes of genomic variations, mainly intragenomic recombination and horizontal gene transfer events.

Currently, genetic typing of microorganisms is widely used in several major fields of microbiological research, as a tool in monitoring of hospital infections, for epidemiological investigations to confirm or negate relationships of clonal strains, in the study of pathogenesis, phylogenetic studies, population genetics of microorganisms or taxonomy. DNA fingerprinting involves the display of a set of DNA fragments from a specific DNA sample. A variety of DNA techniques is currently available, most of which use PCR for detection of fragments.

The choice of a fingerprinting technique depends on the type of application, such as intraspecific diversity analysis (strain typing to study genetic relationships and bacterial population dynamics, outbreak management for identification of the track and source of bacterial infection) or identification at the species level. Ideally, a fingerprinting technique should require no prior investments in terms of sequence analysis. However, knowledge of the species' variability, CG-content percentage or specific restriction enzyme profile is helpful.

A number of fingerprinting methods which meet these requirements has been developed. Fingerprints are obtained by visualizing only a very minor part of the genome, although with an appropriate level of discriminatory power. In addition to this, they should be relatively rapid and cheap, especially in large-scale population genetic studies. In this view, a particular interest can be observed in rapidly developing techniques which employ oligonucleotide adapters and are known as Ligation-Mediated PCR methods (LM PCR). They are known as a high versatile group of techniques for genomic typing and their versatility arises from the fact that they do not require prior knowledge of the sequence and a virtually unlimited number of restriction fragments can be detected and analyzed in genomes.

\section{FRAMEWORK OF LM PCR METHODS - A GENERAL STRATEGY}

LM-PCR is comprised of a group of genome fingerprinting techniques based on the selective amplification of a subset of DNA fragments generated by restriction enzyme digestion. The fingerprint pattern does not include any specific information about the species or genus of the tested strain; therefore they require the use of the purified DNA from correctly identified species of bacteria, yeast or other microorganisms (thus also the need for pure microorganism culture selection). For all LM PCR methods it is necessary to use intact, non-de-

e-mail: beakrawc@pg.gda.pl

*The results were presented at the 6th International Weigl Conference on Microbiology, Gdańsk, Poland (8-10 July, 2015).

Abbreviations: ADSRRS, Amplification of DNA fragments Surrounding Rare Restriction Sites; AFLP, Amplified Fragment Length Polymorphism; ddLMS PCR, double digestion Ligation Mediated Suppression PCR, recA-ddLMS PCR, double digestion Ligation Mediated Suppression PCR for recA gene; rrn-ddLMS PCR, double digestion Ligation Mediated Suppression PCR for rrn-locus; FLAP, Fast Ligation Amplification Polymorphism; FLiP, Fast Ligation-Mediated PCR; IRS PCR, Infrequent-Restriction-Site Amplification; LM PCR, Ligation-Mediated PCR; LM PCR/Shifter, Ligation Mediated PCR/ Shifter; MIRU-VNTR, Mycobacterial Interspersed Repetitive-UnitVariable-Number Tandem-Repeat; PCR, Polymerase Chain Reaction; PCR MP, PCR Melting Profiles; PFGE, Pulse Field Gel Electrophoresis; REA PFGE, Restriction Enzyme Analysis with Pulse Field Gel Electrophoresis; RFLP, Restriction Fragment Length Polymorphism; $T_{d}$, denaturation temperature 
A. Restriction fragment with e.g 5' cohesive

ends

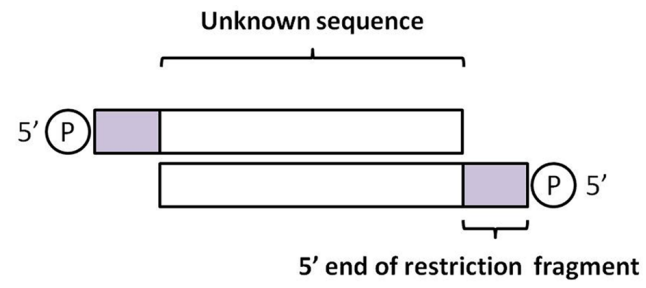

B. Adapter

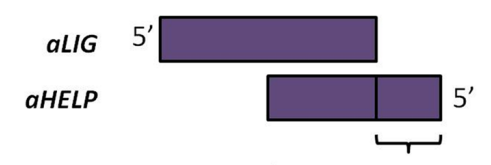

complementary sequence to the $5^{\prime}$ cohesive end of restriction fragments

C. The adapters are ligated to the restriction fragments at both sides (only aLIG oligonucleotide is ligated to the 5 ' ends of DNA fragment).

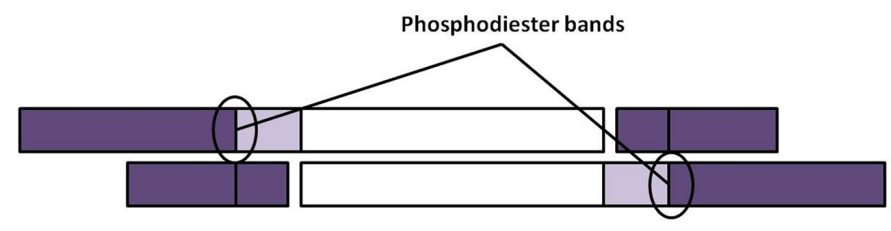

D. Following unligated aHELP oligonucleotides are release and then DNA polymerase fill the $\mathbf{3}^{\prime}$ ends based on the ligated oligonucleotide as a template DNA.

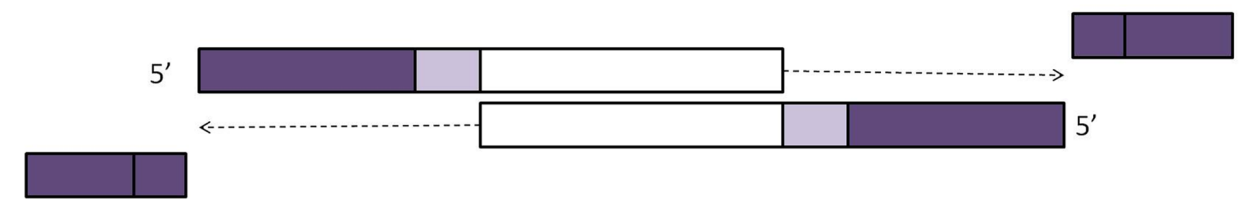

Figure 1. General strategy of LM PCR methods.

graded DNA (50-500 ng) for obtaining readable profiles and for a good reproducibility.

The LM PCR procedure consists of three steps (Fig. 1). In the first step, a total genomic DNA is digested with one or two restriction enzyme(s) giving 5' and/or 3' cohesive ends (Fig. 1A). The enzymes should not be sensitive to DNA methylation. The choice of restriction enzymes depends on the LM PCR variant method. In the second step, double-stranded linkers (synthetic DNA adapters) with complementary sticky ends are ligated to the restriction fragments. The adapter is formed by mixing a helper oligonucleotide (aHELP) and appropriate ligated oligonucleotides (aLIG) (Fig. 1B). The helper oligonucleotide contains a sequence complementary to the sequence of hanging end of the restriction fragment and it is responsible for leading ends of the double-stranded adapter to the appropriate restriction fragments. The ligated oligonucleotide participates in the formation of a phosphodiester bond with a 5' sticky end generated by restriction enzyme and becomes part of the target DNA in the PCR (Fig. 1C). In the third step, selective PCR is carried out. Each of the LM PCR variant methods differs in the way of selecting fragments to be amplified by PCR. In pre-PCR, dissociation of unligated helper oligonucleotide occurs in initial denaturation step and next a thermostable DNA polymerase fills in the free 3' ends based on the ligated oligonucleotide as a template DNA (Fig. 1D). The adapters (linkers) contain each restriction site sequences and sequences homologous to a PCR primer binding site. Finally, selec- tive amplification by PCR occurs (Figs. 2-6). As a result of PCR, DNA products of different length are obtained and can be visualized after electrophoretic separation as a unique band pattern, or peaks in the case of capillary gel electrophoresis (fingerprint patterns). Differences in these fingerprints between individuals are interpreted as genetic distances.

\section{AMPLIFIED FRAGMENT LENGTH POLYMORPHISM (AFLP)}

The AFLP technique, described for the first time by Vos et al. (1995), is based on the detection of genomic restriction fragments by PCR amplification, and can be used for DNAs of any origin or complexity for studying genetic relationships at the species level. The basic AFLP procedure is summarized in a schematic flowchart in Fig. 2. The target DNA is digested with a pair of restriction enzymes (RE1 and RE2, producing three types of DNA fragments (RE1-RE1, RE1-RE2, and RE2-RE2). In most commercial kits for the AFLP method, DNA is subjected to digestion with two different enzymes, one with an average cutting frequency (like EcoRI) and a second one with a higher cutting frequency (like MseI). Since the original publication by Vos et al. (1995), several enzyme combinations have been used, such as EcoRI, PstI, HindIII, or ApaI combined with MseI or TaqI (van der Wurff et al., 2000). For this step, it is crucial to ensure complete digestion because incomplete restriction of the DNA causes problems in the AFLP in- 


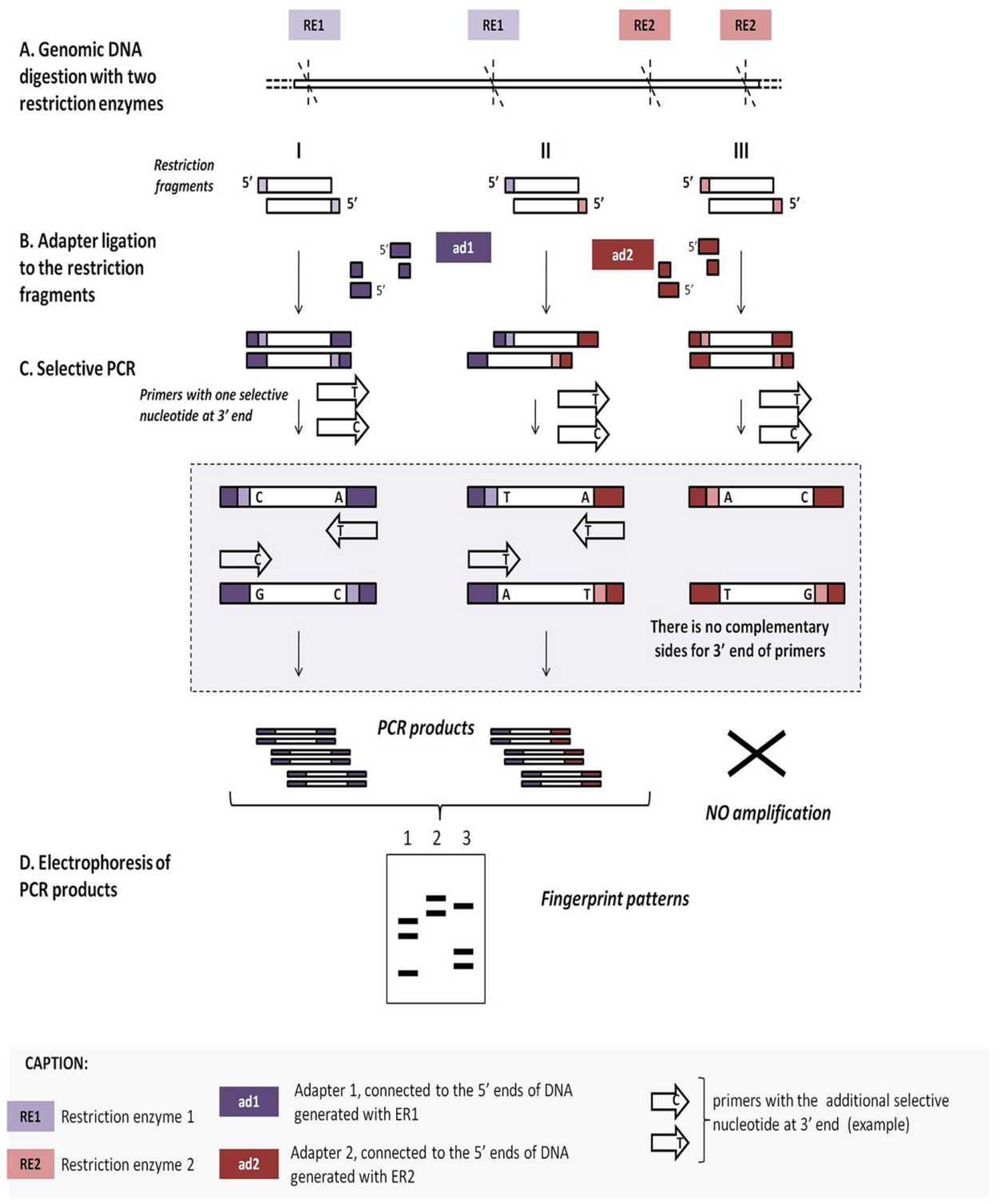

Figure 2. Outline of AFLP method.

terpretation. Amplification of fragments that are not fully digested generates an altered banding pattern and may be misinterpreted as polymorphisms. Next, double-stranded ad1 (for RE1) and ad2 (for RE2) synthetic DNA adapters with complementary sticky ends are ligated to the restriction fragments. Double-stranded adapters consist of a core sequence and an enzyme-specific sequence. For eukaryotic organisms, in the pre-selective amplification, a subset of all the fragments is amplified, using primers that are complementary to the linker sequences with the addition of one nucleotide (A, G, C or T) at the 3'end of the primer. These 'pre-amp' primers will only prime DNA synthesis of fragments with bases flanking the restriction sites that are complementary to the selective nucleotides of the primers, thus reducing the number of fragments to about $1 / 16$ of the initial amount (this can be visualized as a smear when run on an ordinary agarose gel). The number of fragments should be further reduced to a suitable number to be visualized by electrophoresis by a second round of PCR (selective amplification), in which the PCR primers have an additional two to four selective bases at their 3' ends. The number of se- lective nucleotides on the selective primers should increase with the increasing genome size. By using a combination of several primers (e.g. three primers for small genomes and four primers for large genomes) even single differences between closely related organisms can be detected. For microorganisms (including the eukaryotic ones) no 'pre-amp' is needed. In order to visualize the patterns, one of the PCR primers contains either a radioactive (Dijkshoorn et al., 1996; Janssen et al., 1996; Janssen et al., 1997; Gibson et al., 1998) or a fluorescent (Koeleman et al., 1998) label. Polyacrylamide gel electrophoresis (pattern of bands) or capillary gel electrophoresis (visualized as peaks) with manual or with an automated sequencer are used to detect the subset of amplified fragments. The number of fragments is dependent on the resolution of the detection system. Typically 50-100 restriction fragments are amplified in range size from 60 to $500 \mathrm{bp}$. An agarose gel electrophoresis may be also used (in such case it is not necessary to label primers) and the patterns may be examined under UV light after staining with ethidium bromide (Gibson et al., 1998) but then fragment length differences of less than 10 nucleotides 
Table 1. AFLP method - advantages, disadvantages and advice for users

\begin{tabular}{|c|c|c|}
\hline Advantages & Disadvantages & Advice for users \\
\hline $\begin{array}{l}\text { - offers a relatively fast and inexpensive } \\
\text { method for genotyping a large number } \\
\text { of individuals with a high degree of reso- } \\
\text { lution and without prior genetic informa- } \\
\text { tion knowledge } \\
\text { - easy, adaptable technique for many } \\
\text { studies on plants, animals, fungi and } \\
\text { bacteria } \\
\text { - regulation of discrimination power by } \\
\text { the use of a series of different primer } \\
\text { combinations } \\
\text { - high discriminative power between and } \\
\text { within species (resolution of genetic dif- } \\
\text { ferences, high stringency), good ability } \\
\text { to differentiate clonally derived strains } \\
\text { (Dijkshoorn et al., 1996; Janssen et al., } \\
\text { 1996; Janssen et al., 1997; Gibson et al., } \\
\text { 1998; Koeleman et al., 1998) } \\
\text { - high reproducibility (Dijkshoorn et al., } \\
\text { 1996; Janssen et al., 1996; Koeleman et } \\
\text { al.,1998) } \\
\text { - highly automated, many types of } \\
\text { software are available (so reliability is } \\
\text { obtained) }\end{array}$ & $\begin{array}{l}\text { - substantial experience of the person } \\
\text { carrying out the assay is required } \\
\text { - the large number of amplified DNA frag- } \\
\text { ments (e.g. 100) - a software is necessary } \\
\text { for analysis } \\
\text { - for PAGE, problem with single-nucleotide } \\
\text { differences between AFLP fragments } \\
\text { - it is the difficult to identify homologous } \\
\text { markers } \\
\text { - radiolabeled primers reduce the work } \\
\text { flow flexibility and AFLP analysis (Hartl \& } \\
\text { Seefelder, 1998; Huang \& Sun, 1999) } \\
\text { - capillary electrophoresis requires ad- } \\
\text { justment and optimization of existing } \\
\text { protocols for use without dependency on } \\
\text { genome complexity } \\
\text { - scoring background noise (Vekemans et } \\
\text { al., } 2002 \text { ) } \\
\text { - lack transparent reporting of error rates } \\
\text { (Crawford et al. } 2012 \text { ); according to Bonin } \\
\text { et al. (2004) the error rate per locus has } \\
\text { been estimated between } 2-5 \% \\
\text { - existing commercial kits are inapplicable } \\
\text { to certain species, especially those with } \\
\text { large and complex genomes }\end{array}$ & $\begin{array}{l}\text { - a frequently cutting enzyme with a short } \\
\text { recognition sequence rich in A and T may be } \\
\text { more appropriate for organisms whose geno- } \\
\text { mes are rich in these nucleotides } \\
\text { - the use of the Trul restriction enzyme inste- } \\
\text { ad of the commonly used Msel is suggested } \\
\text { - a cheaper isoschizomer can produce bet- } \\
\text { ter quality results (Bensch \& Akesson, 2005) } \\
\text { - discriminatory power can be changed by } \\
\text { replacing the EcoRI enzyme (and the cor- } \\
\text { responding adapter) with a more frequent } \\
\text { cutting enzyme, e.g. Taql (4 bp recognition } \\
\text { site) - an increase of the number of ampli- } \\
\text { fied fragments with approximately one order } \\
\text { of magnitude } \\
\text { - in order to produce easily scored gels you } \\
\text { should extend the selective primers by an } \\
\text { additional fourth base; it could be useful in } \\
\text { combination with an increasing annealing } \\
\text { temperature to maintain the target specificity } \\
\text { - IRDye infrared dye (IRD) or other fluore- } \\
\text { scently labeled oligonucleotide primers inste- } \\
\text { ad of radioactive ones, and fragment analysis } \\
\text { with an automated DNA sequencing instead } \\
\text { of gel electrophoresis improve results }\end{array}$ \\
\hline
\end{tabular}

are difficult to score. Many software programs are available e.g. BioNumerics, GeneMapper or GeneScan for the analysis of AFLP patterns. Advantages, disadvantages and advice for user of the AFLP method are shown in Table 1.

\section{Applications of AFLP}

- The use in molecular typing in epidemiology, especially in short-term outbreaks (Antonishyn et al., 2000; Borst et al., 2003; Ball et al., 2004; Fry et al., 2005; Tavanti et al., 2007).

- Genome mapping and linkage analyses - AFLPs were used to estimate polymorphism rates and to construct AFLP based linkage maps (Martinelli et al., 2005; Kumar et al., 2013).

- Markers for diversity, screen of a large number of random sites throughout the genome, thereby generating sufficient data to make comparisons among populations or taxa (Sunnuck et al., 2000; Grech et al., 2002).

- Phylogenetic reconstructions, bacterial taxonomy (Janssen et al., 1996; Edwards \& Beerli, 2000).

- Genetic diversity and population structure, parental analysis comparisons among populations or taxa (Janssen et al., 1996; Edwards \& Beerli, 2000; Kumar et al., 2013). - Genetic typing for molecular ecology, evolution (Krauss, 1999; Mueller et al., 1999; Bensch \& Akesson, 2005) AFLP band as a locus of specific marker can be isolated - it is possible to extract and sequence the fragment (if electrophoresis is done on polyacrylamide gels) and identify homologous sequences in the database finding markers for genes governing adaptations in wild populations and modifications (Massicotte et al., 2011).

- Measurements of expression variation of multiple genes (cDNA-AFLP) and the distribution of DNA methylation (Bachem et al., 1996; Bachem et al., 1998; Xu et al., 2004; Salmon et al., 2005).

\section{AMPLIFICATION OF DNA FRAGMENTS SURROUNDING RARE RESTRICTION SITES (ADSRRS)}

ADSRRS is a fingerprinting technique based on the digestion of total bacterial DNA with two restriction enzymes differing in cleavage frequency, ligation with two different oligonucleotide adapters and suppression of PCR. PCR suppression (SSH, Suppression Subtractive Hybridization) phenomenon (Diatchenko et al., 1996) constitutes the basis for obtaining a limited representation of the DNA fragments which form the bacterial genome. PCR suppression allows the amplification of only a limited subset of DNA fragments, as only those with two different oligonucleotides ligated at the ends of complementary DNA strands are amplified in the PCR (Masny \& Plucienniczak, 2001). The ADSRRS have been described, modified and optimized for genetic typing of microorganisms in epidemiological studies (Krawczyk et al., 2003a). The outline of that method is shown in Fig. 3. A genomic total DNA is digested with two restriction enzymes, rare (ERC) and frequent (EFC) cutters. Three kinds of DNA fragments — abundant, sporadic, and limited arise that are formed after digestion with frequent, rare and both cutters at the same time, respectively. The mixture of DNA fragments is ligated with two different synthetic adapters, a short adapter (SAd) and a long one (LAd). All of the 5' ends of the most abundant DNA fragments produced by digestion with a frequent cutter (EFC) are modified by joining with the same long synthetic oligonucleotide. Similarly, sporadic fragments generated by digestion with a rare cutter (ERC) are modified by ligation with the same short synthetic oligonucleotide to both 5' ends of each dsDNA fragment. After filling in of the modifying oligonucleotides joined to the 5' ends with the use of the DNA polymerase, all single-stranded abundant and sporadic DNA fragments have complementary sequences at their 5' and 3' ends (they create the so called "panhandle" structures) and because of that, the proper usage of suppression PCR (SP PCR) during amplification of the genomic fragment mixture should eliminate the most and least abundant DNA fragments from the mixture. The PCR suppression depends on (i) the presence and length of the complementary sequences at the terminal ends of the restriction fragments ligated with adapters (ii) the length of the primer - shorter than an adapter is preferred, (iii) PCR suppression is stronger for short fragments, (iv) PCR suppression is inversely proportional to the concentration of the primers - competition be- 


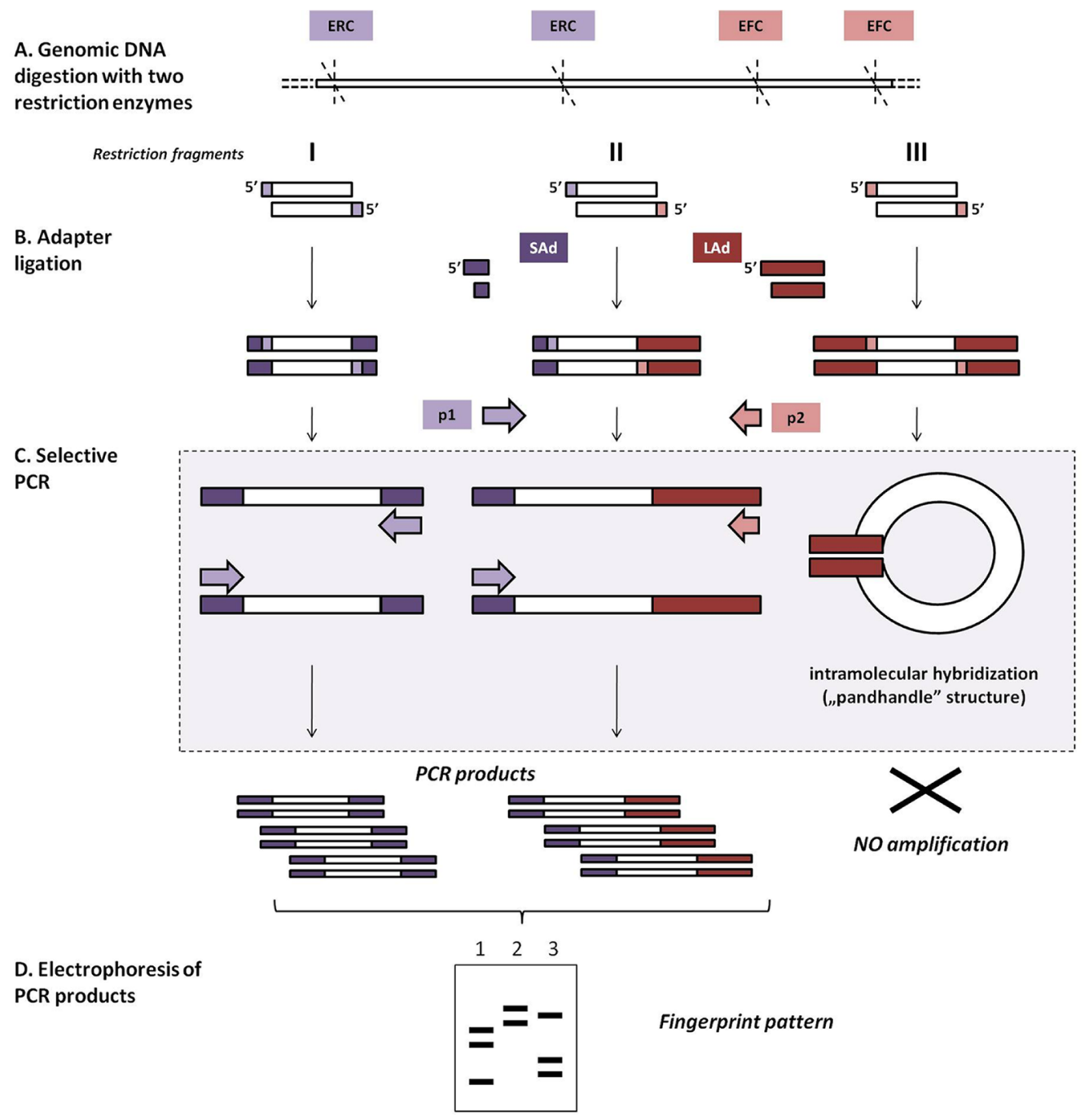

CAPTION:
ERC Enzyme rare cutter
EFC Enzyme frequent cutter

Adapter connected to the $5^{\prime}$ ends of DNA generated with ERC generated with EFC

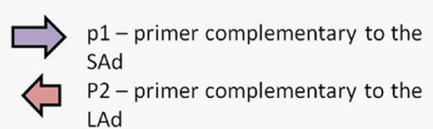
LAd

Figure 3. Outline of ADSRRS method.

tween the primer annealing and "panhandle" structure creation.

However, fragments arising after digestion with rare and frequent restriction enzymes at the same time, and consequently joined with two distinct modifying oligonucleotides, are amplified exponentially. After filling in of the modifying oligonucleotides joined to the 5' ends with the use of the DNA polymerase, single-stranded fragments do not have complementary sequences at their 5' and 3' ends, and consequently are not susceptible to SP PCR. Advantages, disadvantages and advice for users of the ADSRRS method are presented in Table 2.

\section{Applications of ADSRRS}

The method is useful in epidemiological investigations as was shown for genotyping of many clinically important bacteria such as Enterococcus faecium (Krawczyk et al., 2003a), Serratia marcesens (Krawczyk et al., 2003b), Klebsiella pneumoniae (Krawczyk et al., 2005), Staphylococcus aureus (Krawczyk et al., 2007a), Corynebacterium pseudotuberculosis
(Stefańska et al., 2008), Campylobacter jejuni and Campylobacter coli (Krutkiewicz et al., 2010).

\section{INFREQUENT-RESTRICTION-SITE AMPLIFICATION (IRS PCR)}

The method referred to as infrequent-restriction-site PCR (IRS-PCR) assay (Mazurek et al., 1996) consists of double digestion of genomic DNA with a restriction enzyme that infrequently cuts (RE1) the chromosome giving 5' sticky ends, and a second enzyme that cuts frequently (RE2) giving 3' sticky ends. Restriction fragments produced by digestion with an RE1 enzyme are modified by joining adapters ad1 for which the helper oligonucleotide (aHELP) has a phosphate group at the 5' end. But DNA fragments produced by digestion with an ER2 enzyme are modified by joining a synthetic adapter ad2 without a phosphate group, so the helper oligonucleotide $(a H E L P)$ is removed from this adapter during the denaturation step and this leads to loss of binding sites 
Table 2. ADSRRS method - advantages, disadvantages and advice for users

\begin{tabular}{|c|c|c|}
\hline Advantages & Disadvantages & Advice for users \\
\hline $\begin{array}{l}\text { - this method is considered to be reproducible } \\
\text { and versatile, and is very useful in studies of clo- } \\
\text { nal relatedness } \\
\text { - at least a similar power of discrimination to } \\
\text { gold-standard PFGE method (Krawczyk et al., } \\
\text { 2003a; Krawczyk et al., 2003b; Krawczyk et al., } \\
\text { 2005) } \\
\text { - one set of adapters and enzymes can be applied } \\
\text { to analyze DNA from diverse species of bacteria } \\
\text { - results obtained in PCRs do not depend on the } \\
\text { thermostable DNA polymerase (Taq polymerase } \\
\text { or Pwo polymerase) or on the thermal cycler used } \\
\text { - there are no technical difficulties in implemen- } \\
\text { tation of the method under laboratory conditions } \\
\text { if a thermal cycler and basic molecular biology } \\
\text { techniques are available } \\
\text { - the results can easily be analyzed, even on poly- } \\
\text { acrylamide gels stained with ethidium bromide } \\
\text { - PCR products can be directly isolated from the } \\
\text { polyacrylamide gel and subsequently sequenced }\end{array}$ & $\begin{array}{l}\text { - this method ensures success } \\
\text { only for small genomes } \\
\text { - analysis of the series of re- } \\
\text { sults of experiments indicates } \\
\text { that the source of endonucle- } \\
\text { ases and reaction buffers used } \\
\text { for enzymatic digestion of } \\
\text { genomic DNA and PCR thermal } \\
\text { profile are critical parameters } \\
\text { for ADSRRS-fingerprinting } \\
\text { methods } \\
\text { - lack of an automated system } \\
\text { and software } \\
\text { interpretation of the patterns } \\
\text { based on the binary system }\end{array}$ & $\begin{array}{l}\text { - it is preferred to use restriction enzymes giving } \\
\text { a } 5 \text { ' hanging ends with four sticky nucleotides } \\
\text { - it is possible to use the restriction enzymes } \\
\text { which recognize the different sequences, but } \\
\text { giving the same sticky ends after cutting; we } \\
\text { can use the same adapter, primer but as a result } \\
\text { we obtain different fingerprint, e.g. BamHI or } \\
\text { Bglll as a frequent cutters enzyme and Xbal or } \\
\text { Spel as a rare cutter enzyme } \\
\text { - digestion and ligation reaction may be carried } \\
\text { out simultaneously, however to improve the } \\
\text { efficiency of ligation it is recommended that it } \\
\text { should be carried out separately } \\
\text { - ligated oligonucleotide from a short adapter } \\
\text { can be also used as a primer in PCR (the same } \\
\text { sequence) } \\
\text { - the primer sequence should be shorter than } \\
\text { linker - this guarantees PCR suppression } \\
\text { - a maximum of } 19-24 \text { amplification cycles is } \\
\text { recommended (more cycles give background } \\
\text { noise) }\end{array}$ \\
\hline
\end{tabular}

for the primer. The process of amplification of restriction fragments depends on the presence of binding sites for the two primers, as a result of the enzyme selection, adapter's structure and primers. Amplification occurs only for fragments that arose from digestion by both, the rare and frequent cutter enzymes, and the fragments obtained by double digestion by the rare cutting enzyme. The number of DNA fragments generated by IRS PCR depends on the primers used. Additionally, a reduction in the number of amplified fragments is achieved by the addition of one selective nucleotide into the primer. The scheme of the procedure is shown in Fig. 4. Advantages, disadvantages and advice for users of the IRS method are described in Table 3.

\section{Applications of IRS-PCR}

This technique has been used, amongst others, in clinical differentiation of isolates belonging to Acinetobacter baumannii and Serratia marcescens (Yoo et al., 1999), Legionella pneumophila (Riffard et al., 1998), Staphylococcus. aureus (Huang et al., 2005), Klebsiella pneumoniae (Su et al., 2000), Coxiella burnetii (Arricau-Bouvery et al., 2006).

\section{PCR MELTING PROFILES (PCR MP)}

The PCR MP technique was developed by Masny and Płucienniczak (2003) and Krawczyk et al. (2006) for genetic typing of microorganisms. The scheme of the procedure is depicted in Fig. 5. A total genomic DNA is completely digested with one type of restriction enzyme, such as HindIII or EcoRI for example. All the 5' ends of DNA fragments produced by digestion are modified by joining the same synthetic oligonucleotides. The selectivity and the differentiating power may be adjusted not only by selection of the appropriate restriction enzyme as for AFLP and ADSRRS, but also by changing the denaturation temperature in the PCR cycles. During PCR, all the DNA fragments in the sample should be amplified, but the lowering of the denaturation temperature during PCR should decrease the number of amplified fragments, since only single-stranded DNA molecules may serve as a template in PCR. The PCR MP technique permits a specific gradual amplification of genomic DNA with differing thermal stability, from the less stable DNA fragments, which are amplified at lower denaturation temperature values, to the more stable ones, these being amplified at higher denaturation temperature values. Prior to differentiation of strains by PCR MP, it is necessary to experimentally select the desired denaturation temperature of PCR cycles using a thermocycler with a temperature gradient. By selecting the denaturation temperature of PCR cycles, a decision is made as to the potential differentiation and complexity of band profiles. It is also very important to determine the denaturation temperature range within which the results are reproducible. The denaturation temperature should be optimized separately for each species of microorganisms. For example denaturation temperature range for Escherichia coli is $85.0-89.0^{\circ} \mathrm{C}$, Enterococcus faecium $79.6-82.5^{\circ} \mathrm{C}$, Staphylococcus aureus $78.3-81.5^{\circ} \mathrm{C}$. The selection of the denaturation temperature at which a sufficient number of products could be obtained is very important for reliability of typing results. In this aspect, the versatility of this method is limited. However, the used of the same restriction enzyme, adapter and primer for typing of many micro-

Table 3. IRS-PCR method - advantages, disadvantages and advice for users

\begin{tabular}{|c|c|c|}
\hline Advantages & Disadvantages & Advice for users \\
\hline $\begin{array}{l}\text { - the IRS-PCR technique can be applied to } \\
\text { a wide range of bacterial microorganisms } \\
\text { while maintaining the same restriction en- } \\
\text { zymes, primers, adapters and amplification } \\
\text { conditions } \\
\text { - the use of minute quantities of target DNA } \\
\text { - the separation of amplified fragments can } \\
\text { be achieved by conventional polyacrylami- } \\
\text { de gel electrophoresis }\end{array}$ & $\begin{array}{l}\text { - helper oligonucleotide for ends cre- } \\
\text { ated by rare cutter enzyme should con- } \\
\text { tain the phosphate group which allows } \\
\text { to form a phosphodiester bond with } \\
\text { restriction fragment - increase in the } \\
\text { cost of oligonucleotide synthesis } \\
\text { - detection is based on a binary system; } \\
\text { it does not take into account the inten- } \\
\text { sity of the bands during detection }\end{array}$ & $\begin{array}{l}\text { - it is necessary to use two restriction enzy- } \\
\text { mes, one of them gives a sticky } 5^{\prime} \text { end, the } \\
\text { second one } 3^{\prime} \text { ends } \\
\text { - frequent cutter enzyme should give the } 3^{\prime} \\
\text { sticky ends } \\
\text { - regulation of discriminatory power can be } \\
\text { obtained by choice of the suitable restriction } \\
\text { enzymes and by the } 3^{\prime} \text { end of primer } \\
\text { - ligation efficiency increases for }>3 \text { bases at } \\
5^{\prime} \text { hanging ends }\end{array}$ \\
\hline
\end{tabular}




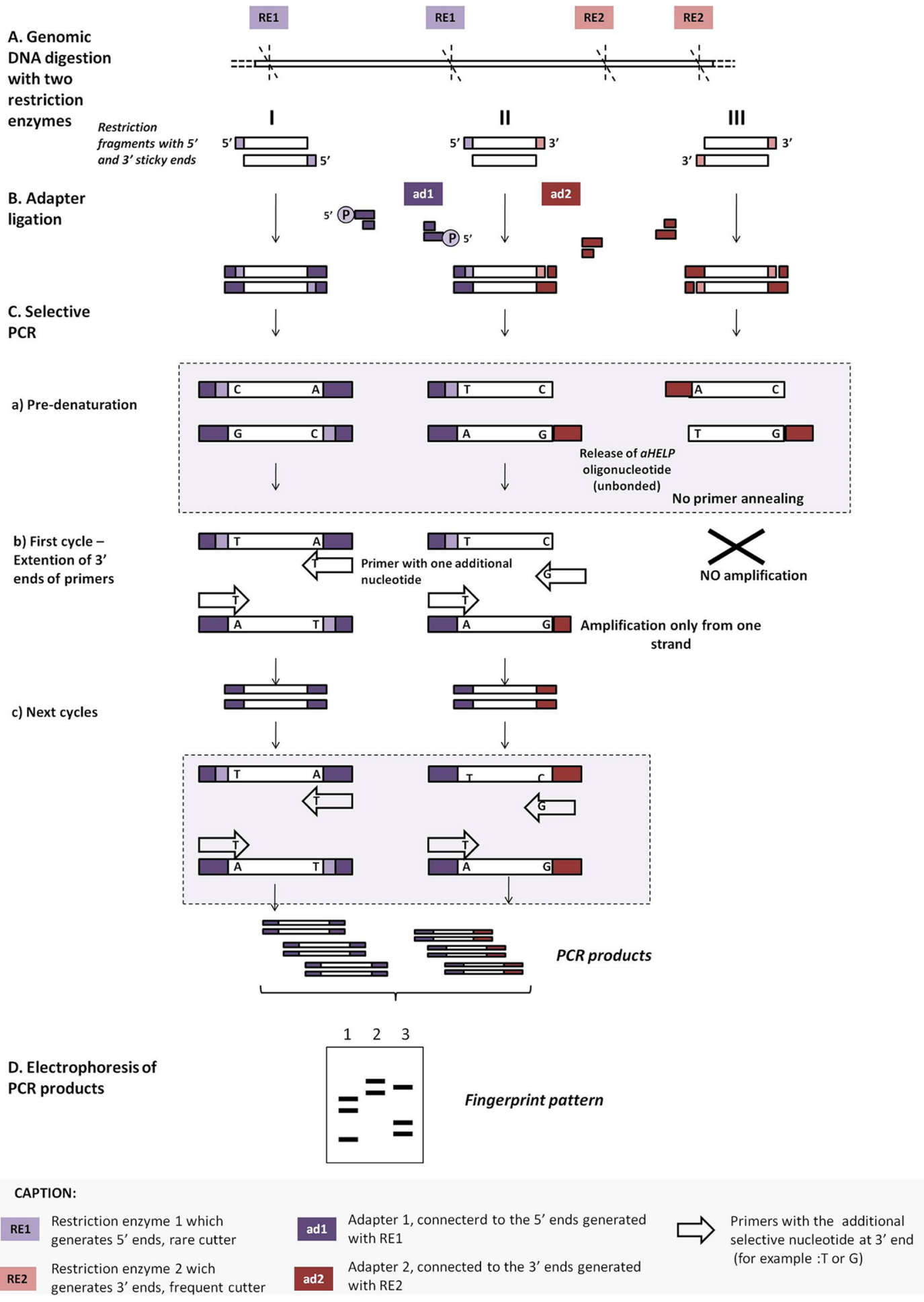

Figure 4. Outline of IRS method.

organisms makes this method flexible. Advantages, disadvantages and advice for users of the PCR MP method are described in Table 4.

\section{Applications of PCR MP}

- The use of PCR MP in various aspects of epidemiological studies. The PCR MP technique can be used as an alternative technique for generating DNA profiles in epidemiological studies of intra-species genetic relatedness of bacterial, yeast and dermatophytes strains, similarly to REA-PFGE which is regarded as the "gold standard" in genotyping.

- The possibility of the use in the study of genetic relationships of microbe isolates (bacteria/yeast) obtained from individual patients from hospital wards in order to establish the epidemiological relationship between strains (e.g. associated with their likely transmission from the gastrointestinal tract into the blood system and association with nosocomial infections).

- The possibility of use in a study of bacterial carriers and colonization (Krawczyk et al., 2007a). 
A. Genomic DNA
digestion with one restriction enzyme
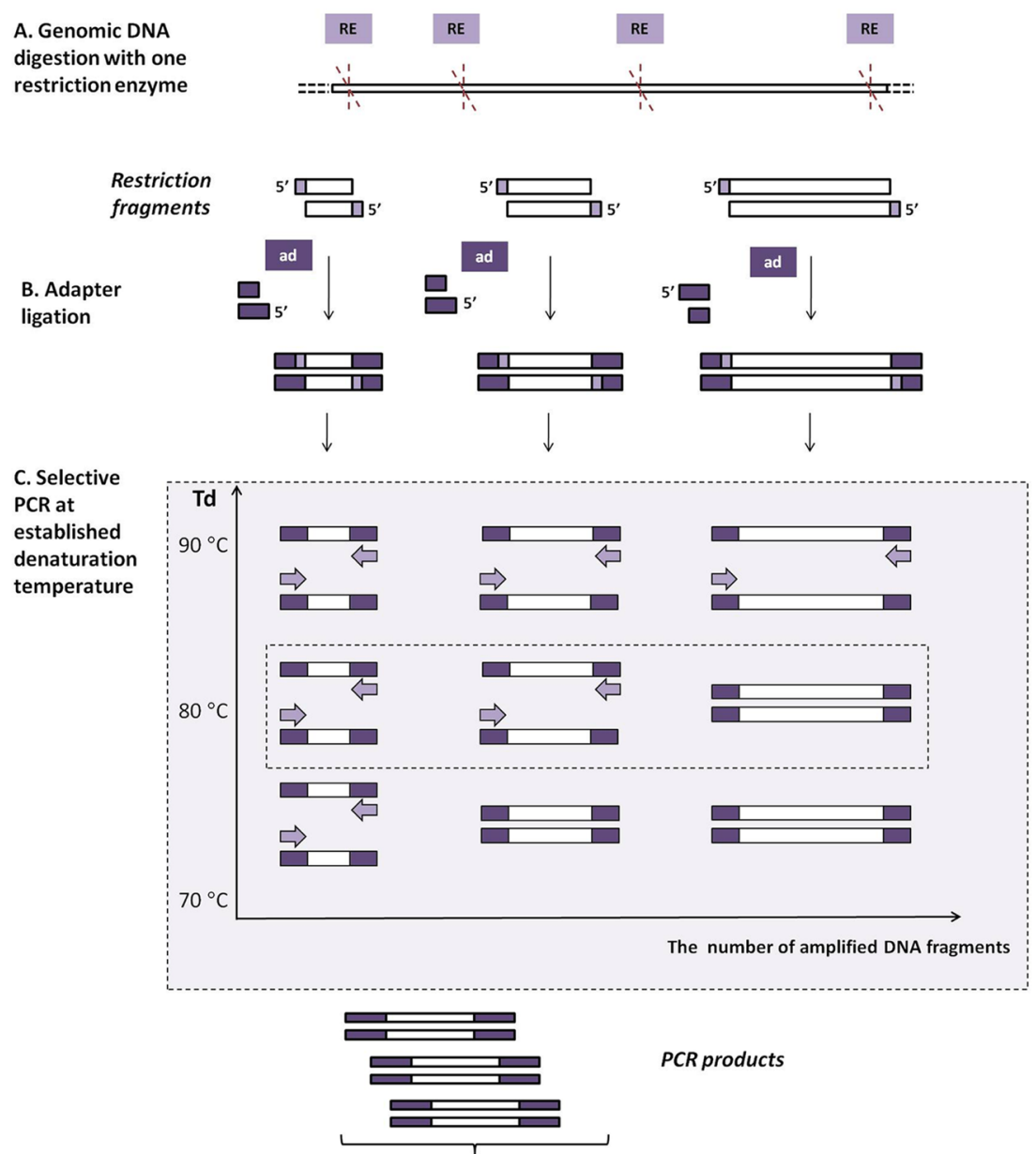

D. Electrophoresis of PCR products

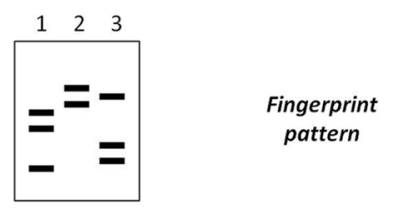

CAPTION:

RE Restriction enzyme

Adapter connected to the ends generated with RE $\Rightarrow$ primer

Figure 5. Outline of PCR MP method.

- Verification of the genotyping results for genetically related strains (analysis of the short-temperature gradient PCR cycles) e.g. from short-term episodes (Krawczyk et al., 2006).

- The usefulness of the PCR MP technique in the study of persistent and recurrent bacteremia (Krawczyk et al., 2007b).

- PCR MP has demonstrated suitability for epidemiological examination of E. coli, Serratia marcescens, Enterococcus faecium, Klebsiella oxytoca, Candida albicans (Krawczyk et al., 2006; Krawczyk et al., 2007; Krawczyk et al., 2009; Stojowska et al., 2009a and 2009b) isolates and the method has been applied to the molecular typing of Staphylococcus aureus strains (Krawczyk et al., 2007a), Corynebacterium diphtheriae isolates (Zasada et al., 2014), Salmonella enterica (Zaczek et al., 2015) and to the intraspecies differentiation of Trichophyton rubrum and Trichophyton interdigitale (Leibner-Ciszak et al., 2010).
- PCR MP bands identified as a locus of a specific marker can be isolated - it is possible to extract and sequence the fragment.

- A method based on ligation-mediated PCR (LM/PCR) using a low denaturation temperature which produces specific melting profile patterns of DNA has been adapted to real-time PCR with high-resolution melting analysis (LM/HRM system) by Woksepp et al. (2011). It allowed an analysis of strains isolated from a given outbreak in a single-tube system within a day.

\section{LIGATION MEDIATED PCR/SHIFTER (LM PCR/SHIFTER)}

The LM PCR/Shifter method relies on the use of a Class IIS restriction enzyme that recognizes nonpalindromic DNA sequences, between 4 and 7 base pairs in length and cuts up to 20 bases outside their target sites, creating different 'sticky ends' up to 5 bases long. Krawczyk et al. (2011) used a Class IIS restriction en- 
Table 4. PCR MP method - advantages, disadvantages and advice for users

\begin{tabular}{|c|c|c|}
\hline Advantages & Disadvantages & Advice for users \\
\hline $\begin{array}{l}\text { - this method may be used to study } \\
\text { DNA from different sources, as well as } \\
\text { large genomes, even eukaryotic ones } \\
\text { - it is known as a method of universal } \\
\text { applicability (does not require specific } \\
\text { oligonucleotides for each species) } \\
\text { - the discrete number of well-resolved } \\
\text { bands generated could readily be ana- } \\
\text { lyzed by direct visual comparison } \\
\text { - it is possible to verify a questiona- } \\
\text { ble genetic pattern through the use } \\
\text { of a short-denaturation temperature } \\
\text { gradient } \\
\text { - it is possible to differentiate DNA } \\
\text { fragments of identical length with a } \\
\text { different nucleotide composition and } \\
\text { this cannot be done by using other } \\
\text { LM PCR techniques }\end{array}$ & $\begin{array}{l}\text { - this method requires the use of a ther- } \\
\text { mocycler with a temperature gradient } \\
\text { option and is highly sensitive to the de- } \\
\text { naturation temperature fluctuations } \\
\text { - before genetic typing of isolates, it is } \\
\text { necessary to implement several prelimi- } \\
\text { nary steps, which include: } \\
\text { - (i) a regular validation/calibration of the } \\
\text { thermocycler; } \\
\text { - (ii) the optimization of the DNA denatu- } \\
\text { ration temperature } \\
\text { - the fingerprinting pattern is reprodu- } \\
\text { cible for a given equipment used, but a } \\
\text { fluctuation in band pattern may be obse- } \\
\text { rved with different thermocyclers, altho- } \\
\text { ugh the grouping should be maintained } \\
\text { (reproducible within the laboratory) } \\
\text { - detection is based on a binary system, } \\
\text { intensity of the bands is not analyzed }\end{array}$ & $\begin{array}{l}\text { - choice of restriction enzymes - class II, giving } \\
\text { about } 300-400 \text { fragments (check in silico for the } \\
\text { tested species) } \\
\text { - the discriminatory power can be regulated by } \\
\text { choice of restriction enzymes (e.g. Hindlll, EcoRl, } \\
\text { Sall, and denaturation temperature values used } \\
\text { in PCR } \\
\text { - the use of primer complementary to the ada- } \\
\text { pter and 5' end of the restriction fragment is } \\
\text { recommended to avoid the suppression PCR } \\
\text { ("panhandle" structure) } \\
\text { - the optimal denaturation temperature for the } \\
\text { PCR MP procedure should be determined during } \\
\text { the optimization experiments with three geneti- } \\
\text { cally unrelated strains; analysis of many patterns } \\
\text { should lead to finding the most stable denatura- } \\
\text { tion temperature to use } \\
\text { - isolates from a particular patient can be tested } \\
\text { with PCR-MP at increasing denaturation tempera- } \\
\text { tures - verification of patterns }\end{array}$ \\
\hline
\end{tabular}

Table 5. LM PCR/Shifter method - advantages, disadvantages and advice for users

\begin{tabular}{|c|c|c|}
\hline Advantages & Disadvantages & Advice for users \\
\hline $\begin{array}{l}\text { - the simplicity of changing discrimination power achieved by } \\
\text { changing the } 4 \text { base discriminative sequences in the adapter } \\
\text { and/or primer without changing the restriction enzyme used } \\
\text { - the PCR conditions can be standardized through the use of } \\
\text { common adapters and primers to allow parallel amplification of } \\
\text { specific restriction fragments with appropriate adapters without } \\
\text { the need to design primers and optimize conditions for each } \\
\text { species typing } \\
\text { - possible to extract and sequence the fragment that repeats } \\
\text { regardless of the } 3^{\prime} \text { primer sequence } \\
\text { - the method is relatively rapid, offering a good discriminatory } \\
\text { power and excellent reproducibility (Krawczyk et al., 2011) } \\
\text { the results can be easily analyzed, even on polyacrylamide gels } \\
\text { stained with ethidium bromide }\end{array}$ & $\begin{array}{l}\text { - a small choice of Class } \\
\text { IIS restriction enzymes } \\
\text { leaving the 'sticky ends' } \\
\text { up to } 4 \text { bases long } \\
\text { - detection is based on } \\
\text { a binary system; it does } \\
\text { not take into account the } \\
\text { intensity of the bands } \\
\text { during detection }\end{array}$ & $\begin{array}{l}\text { - Alw26I restriction enzyme is more } \\
\text { useful for typing of bacteria, but Fokl is } \\
\text { more useful for Candida sp. } \\
\text { - helper oligonucleotide with } 5^{\prime} \text { NCGN } \\
\text { end and mix primers with } 3^{\prime} \text { NGCN } \\
\text { ends give very good results } \\
\text { - the discriminatory power of the me- } \\
\text { thod could be changed by 5' end ada- } \\
\text { pter and/or 3'end primer modification } \\
\text { - limited risk of overlapping fragments } \\
\text { in a pattern can be obtained by redu- } \\
\text { cing the degeneracy of the primers }\end{array}$ \\
\hline
\end{tabular}

zyme such as Alw26I, FokI, giving restriction fragments with different 4 base 5' overhangs. There are 256 possible combinations of the bases at each end of each adapter resulting in 65536 possible 4-base $5^{\prime}$ overhangs (functionally, this equates to 32768 unique 5' overhangs because of directional reversibility of the 5' overhangs). The ligation of the appropriate oligonucleotide adapters corresponding to the cohesive ends of the DNA fragments, and the selective PCR amplification of ligation products (LM PCR), depending on the 5' end sequence of adapter and 3' end sequence of primer(s) were used. The differentiating potential of the method can be adjusted either by using a mixture of adapters with varying degrees of degeneration (the range of degeneration of these oligonucleotides will cause an increase in the number of amplified fragments) or by combining several primer oligonucleotides in one reaction.

The method facilitates bacterial species strain differentiation on the basis of the different DNA band patterns obtained after electrophoresis in polyacrylamide gels stained with ethidium bromide and visualized under UV light. It may be applied for genotyping studies. The scheme of the procedure is depicted in Fig. 6. Advantages, disadvantages and advice for users of the LM PCR/ Shifter method are described in Table 5.

\section{Applications of LM PCR/Shifter}

- The method could be especially useful for inter- and intra-species discrimination of microorganism in long- or short-term epidemics, when different discriminatory power might be necessary.

- The usefulness of LM PCR/Shifter method was tested on the Acinetobacter calcoaceticus-baumannii complex, E. coli, Klebsiella oxytoca, Klebsiella pneumoniae, Serratia marcescens, Enterococcus faecium (Krawczyk et al., 2011).

\section{MODIFIED GENOTYPING METHODS WITH THE USE OF LM PCR}

For LM PCR methods, the fingerprint patterns do not include any specific information about the species or genus of the tested strain. However, there is a variant of LM PCR for screening, typing and identification of selected organisms e.g. recA-ddLMS PCR (double digestion Ligation Mediated Suppression PCR for recA gene) for Acinetobacter calcoaceticus-baumannii complex (interspecific differences) or rrn-ddLMS PCR (double digestion Ligation Mediated Suppression PCR for rrn-locus) for Acinetobacter baumannii (intraspecific typing) (Stojowska \& Krawczyk, 2014). The double digestion Ligation Mediated Suppression PCR method is designed to study polymorphism of the sequence upstream from the specific target sequence (species- or genus-specific). In this method only specific restriction fragments containing a genus- or species-specific target sequence are amplified, and it is unnecessary to use genomic DNA isolated from a previously purified bacterial colony. 


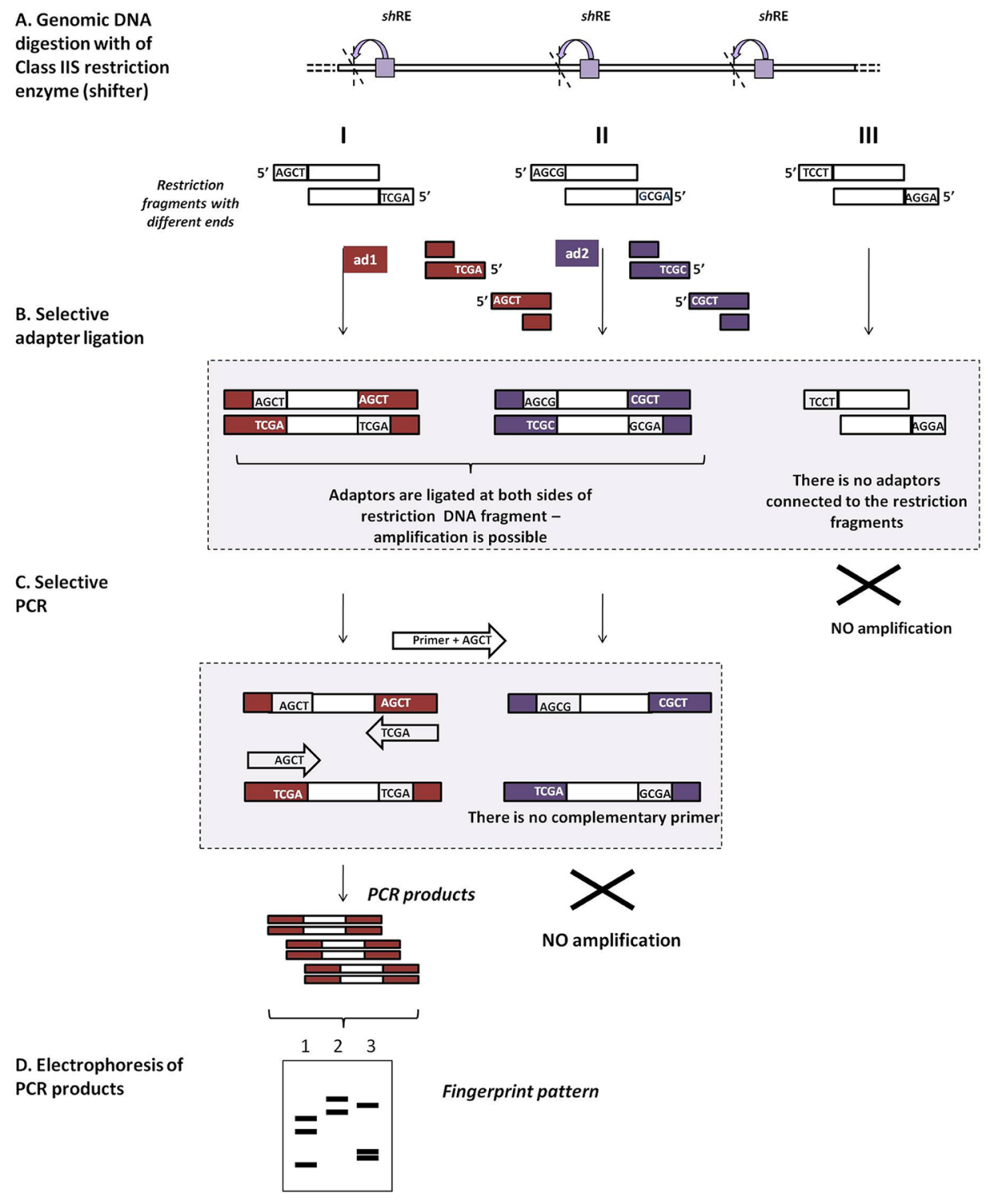

\section{CAPTION:}

\begin{tabular}{|c|}
\hline AGCT \\
\hline AGCG \\
\hline TCCT \\
\hline
\end{tabular}

Different sequences of $5^{\prime}$ ends of restriction DNA fragments $\left(5^{\prime} \rightarrow 3^{\prime}\right)$ ad1

Adapter 1, with known sequence
Recognition sites of Class IIS restriction enzyme

Primer, complementary to the adapter with AGCT 3'end (for example)

Figure 6. Outline of LM/PCR Shifter method.

Another example of the modified genotyping method with the use of LM PCR is a procedure to amplify the flanking sequences on both sides of the insertion sequence (IS6110) for Mycobacterium tuberculosis (Palittapongarnpim et al., 1993). A variation of this method was used by Prod'hom et al. (1997) to only amplify the upstream IS6110-flanking region. The other modification of this method was Fast LigationMediated PCR (FLiP) (Reising et al., 2005; Zaczek et al., 2013) and recently developed Fast Ligation Amplification Polymorphism (FLAP) analysis (Zaczek et al., 2014). According to the authors, this method is a specific and valuable molecular tool for analyzing $M$. tuberculosis strains with high discriminatory power as a MIRU-VNTR.

\section{SUMMARY AND CONCLUSIONS}

Genomic fingerprinting can give a snapshot of variations at the whole-genome level or focus on smaller amplified genomic regions (PCR-based approaches). This first group of methods is more versatile and simultaneously has a high discriminatory power. The LM PCR technology is a DNA fingerprinting technique that combines both, RFLP and PCR fingerprinting strategies. The comparison of LM PCR procedures is shown in Table 6. These methods are extremely adaptable. Each method has a different system of selection of the amplified fragments (selective primers with additional nucleotides at 3' ends for AFLP, PCR suppression for ADSRRS, lower $T_{d}$ in PCR cycles for PCR MP, or selective adapters and prim- 
Table 6. Comparison of the LM PCR procedures

\begin{tabular}{|c|c|c|c|c|c|}
\hline \multirow{3}{*}{ 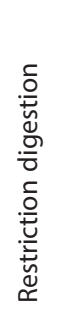 } & AFLP & ADSRRS & PCR MP & LM PCR/Shifter & IRS PCR \\
\hline & \multicolumn{5}{|c|}{ whole genomic DNA; do not require prior knowledge of an analyzed sequence } \\
\hline & $\begin{array}{l}\text { Two Class II restric- } \\
\text { tion enzymes: a rare } \\
\text { and frequent cutter } \\
\text { (RC and FC) giving } 5^{\prime} \\
\text { hanging ends } \\
\text { e.g. Msel/EcoRI }\end{array}$ & $\begin{array}{l}\text { Two Class II restriction } \\
\text { enzymes: a rare and fre- } \\
\text { quent cutter (RC and FC) } \\
\text { giving } 5 \text { ' hanging ends } \\
\text { e.g. Bglll/Xbal }\end{array}$ & $\begin{array}{l}\text { One Class II re- } \\
\text { striction enzyme, a } \\
\text { frequent or middle } \\
\text { cutter (FC) giving } \\
5^{\prime} \text { hanging ends } \\
\text { e.g. Hindlll }\end{array}$ & $\begin{array}{l}\text { One Class IIS re- } \\
\text { striction enzyme } \\
\text { giving } 5^{\prime} \text { han- } \\
\text { ging ends e.g. } \\
\text { Alw26l or Fokl }\end{array}$ & $\begin{array}{l}\text { Two Class II restriction } \\
\text { enzymes giving a } 3^{\prime} \text { han- } \\
\text { ging end for frequent } \\
\text { cutter (FC) and } 5^{\prime} \text { hanging } \\
\text { end for rare end (RC) } \\
\text { e.g. Hhal/Xbal }\end{array}$ \\
\hline 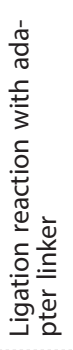 & $\begin{array}{l}\text { Two adapters (witho- } \\
\text { ut phosphate group } \\
\text { at } 5^{\prime} \text { end) with com- } \\
\text { plementary overhang } \\
\text { to restriction sites }\end{array}$ & $\begin{array}{l}\text { Two adapters (without } \\
\text { phosphate group at 5' } \\
\text { end) with complementa- } \\
\text { ry overhang: "short" liga- } \\
\text { ted to RT sites and "long" } \\
\text { ligated to CT sites }\end{array}$ & $\begin{array}{l}\text { One short adapter } \\
\text { (without phosphate } \\
\text { group at } 5^{\prime} \text { end) } \\
\text { ligated to restric- } \\
\text { tion sites }\end{array}$ & $\begin{array}{l}\text { Mixed adapters } \\
\text { (without pho- } \\
\text { sphate group } \\
\text { at 5' end) with } \\
\text { complemen- } \\
\text { tary overhang } \\
\text { 5'NGCN to } \\
\text { 3'NGCN ends } \\
\text { restriction sites. } \\
\text { 5'adapter ends } \\
\text { as a selection } \\
\text { factor }\end{array}$ & $\begin{array}{l}\text { Two adapters with } 5^{\prime} \\
\text { and } 3^{\prime} \text { complementary } \\
\text { overhang (with phospha- } \\
\text { te group at } 5^{\prime} \text { end for } \\
\text { aHELP oligonucleotide in } \\
\text { case of RC) }\end{array}$ \\
\hline 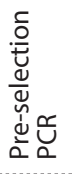 & $\begin{array}{l}\text { Only for eukaryotic } \\
\text { organisms } \\
\text { pre-selective primers } \\
+1 \mathrm{nt}\end{array}$ & no & no & no & no \\
\hline 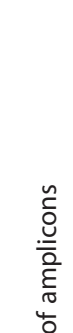 & $\begin{array}{l}\text { PCR-2 selective pri- } \\
\text { mers with } 2-3 \text { addi- } \\
\text { tional nucleotides at } \\
3^{\prime} \text { ends. } \\
\text { Selection: } \\
\text { reducing the number } \\
\text { of amplified frag- } \\
\text { ments is } 4^{n} \text { where } \\
\text { " } n \text { " is the number of } \\
\text { selective nucleotides; }\end{array}$ & $\begin{array}{l}\text { Two primers "short" and } \\
\text { "long" } \\
\text { Selection: } \\
\text { PCR suppresion- pan- } \\
\text { handle structure for frag- } \\
\text { ments with long primer, } \\
\text { the same adapters }\end{array}$ & $\begin{array}{l}\text { Primer is longer } \\
\text { than the ligated } \\
\text { oligonucleotide } \\
\text { with the sequence } \\
\text { of restriction site } \\
\text { Selection based on } \\
\text { the amplification of } \\
\text { the unstable DNA } \\
\text { fragments by apply- } \\
\text { ing a relatively low } \\
\mathrm{T}_{\mathrm{d}} \text { PCR in cycles; }\end{array}$ & $\begin{array}{l}\text { Selection: } \\
\text { depends on } \\
5^{\prime} \text { end of adapter } \\
\text { and } 1-4 \text { selective } \\
\text { primers with } 3^{\prime} \\
\text { NGCN ends }\end{array}$ & $\begin{array}{l}\text { PCR - two selective pri- } \\
\text { mers with } 1 \text { additional } \\
\text { nucleotide at } 3^{\prime} \text { ends } \\
\text { no primer binding sites } \\
\text { for FC fragments }\end{array}$ \\
\hline 뜬 & $\begin{array}{l}\text { About } 50-100 \text { coam- } \\
\text { plicons }\end{array}$ & $\begin{array}{l}\text { About 10-25 coampli- } \\
\text { cons }\end{array}$ & $\begin{array}{l}\text { About 10-25 coam- } \\
\text { plicons }\end{array}$ & $\begin{array}{l}\text { About } 10-20 \\
\text { coamplicons }\end{array}$ & About $10-20$ coamplicons \\
\hline 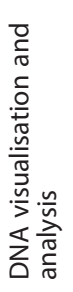 & $\begin{array}{l}\text { Pre-selective PCR } \\
\text { amplification with } \\
\text { primer without la- } \\
\text { belling. } \\
\text { Selective PCR am- } \\
\text { plification with dif- } \\
\text { ferent primers each } \\
\text { labelled } \\
\text { Capillary electropho- } \\
\text { resis }\end{array}$ & Gel electrophoresis, ethidiu & Im bromide, UV light & & \\
\hline 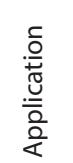 & $\begin{array}{l}\text { For big and small } \\
\text { genomes } \\
\text { (bacteria, yeast, } \\
\text { plants, parasites) }\end{array}$ & $\begin{array}{l}\text { For small genomes (bac- } \\
\text { teria were the only ones } \\
\text { checked) }\end{array}$ & $\begin{array}{l}\text { For big and small } \\
\text { genomes } \\
\text { (bacteria, yeast, } \\
\text { dermathophytes) }\end{array}$ & $\begin{array}{l}\text { For small geno- } \\
\text { mes } \\
\text { (bacteria were } \\
\text { the only ones } \\
\text { checked) }\end{array}$ & $\begin{array}{l}\text { For small genomes (bac- } \\
\text { teria were the only ones } \\
\text { checked) }\end{array}$ \\
\hline
\end{tabular}

ers in the case of IRS and LM-PCR/ Shifter) suited to the needs and possibilities of a given laboratory (Table 6). Discriminatory power for each method also depends on the restriction enzyme(s) used at the first step of the method, so it is very important to know the in silico established range of cutting frequency for a given species, e.g. for ADSRRS and PCR MP 300-400 cutting sites are recommended. The use of different enzymes can generate a set of different patterns. Polymorphisms detected in DNA fingerprints obtained by restriction cleavage can result from alterations in the DNA sequence, including mutations abolishing or creating a restriction site, and insertions, deletions, or inversions between two restriction sites. The LM PCR methods are simple, affordable, intralaboratory reproducible, with reproducibility comparable to the REA PFGE or better (Krawczyk et al., 2003a; Krawczyk et al., 2003b; Krawczyk et al., 2005; Krawczyk et al., 2006; Krawczyk et al., 2007a; Krawczyk et al., 2007b; Krawczyk et al., 2009), and these advantages make LM PCR techniques a good tool for epidemiological studies (Table 7). Except for AFLP, they neither require substantial experience on the part of person carrying out the assay, nor expensive equipment. Non-degraded good quality DNA is needed, but not as much as 
Table 7. Characteristics of the methodology

\begin{tabular}{|c|c|c|c|c|c|c|c|}
\hline LM PCR method & Typeability & $\begin{array}{l}\text { Quantity of } \\
\text { genomic } \\
\text { DNA for test } \\
\text { (ng) }\end{array}$ & $\begin{array}{l}\text { Intra-laboratory } \\
\text { reproducibility }\end{array}$ & $\begin{array}{l}\text { Inter-laboratory } \\
\text { reproducibility }\end{array}$ & $\begin{array}{l}\text { Discriminato- } \\
\text { ry power }\end{array}$ & Versatility & $\begin{array}{l}\text { Ease of per- } \\
\text { formance }\end{array}$ \\
\hline AFLP & $\begin{array}{l}\text { Excellent for all } \\
\text { microorganisms }\end{array}$ & $50-500$ & Good & Good & Excellent & Yes & Good \\
\hline ADSRRS & $\begin{array}{l}\text { Excellent for bac- } \\
\text { teria }\end{array}$ & $100-200$ & Excellent & Excellent & High & Yes & Excellent \\
\hline PCR MP & $\begin{array}{l}\text { Excellent for bac- } \\
\text { teria, yeast, Tricho- } \\
\text { phyton }\end{array}$ & $30-400$ & Excellent & Good & Excellent & Yes & Excellent \\
\hline LM PCR/ Shifter & $\begin{array}{l}\text { Excellent for bac- } \\
\text { teria }\end{array}$ & $100-400$ & Good & nd & High & & Excellent \\
\hline IRS PCR & $\begin{array}{l}\text { Excellent for bac- } \\
\text { teria }\end{array}$ & $100-400$ & Excellent & Good & High & Yes & Excellent \\
\hline LM PCR method & $\begin{array}{l}\text { Time } \\
\text { [h] }\end{array}$ & Automation & $\begin{array}{l}\text { Ease of inter- } \\
\text { pretation }\end{array}$ & Software & Cost & Availability & \\
\hline AFLP & 12 & Yes & Fair & Yes & High & $\begin{array}{l}\text { Home-made, } \\
\text { Commercial }\end{array}$ & \\
\hline ADSRRS & 3 & No & Excellent & No & Low & $\begin{array}{l}\text { Home-made, } \\
\text { Commercial }\end{array}$ & \\
\hline PCR MP & 8 & No & Excellent & No & Low & $\begin{array}{l}\text { Home-made, } \\
\text { Commercial }\end{array}$ & \\
\hline LM PCR/ Shifter & 3 & & Excellent & No & & Home-made & \\
\hline IRS PCR & 3 & No & Excellent & No & Low & Home-made & \\
\hline
\end{tabular}

for PFGE (permissible alkaline lysis). Detection of amplified fragments is limited to $<3000 \mathrm{bp}$ because it depends on the use of polyacrylamide gels. However, these methods can be also performed with agarose gels (e.g. AFLP) with a different range of fragment length, but one should be aware that the sensitivity of detection of amplified fragments will be significantly decreased. These methods are also characterized by a short time of analysis; for ADSRRS, PCR MP, LM PCR/Shifter only 19-24 PCR cycles are required for amplification of restriction fragments. In most cases, it is possible to obtain the typing results within 3-8 hours (after DNA extraction).

Due to the need for digestion of DNA and ligation of the adapters, contamination with foreign DNA coming from the environment is unlikely in spite of the amplification events.

Notwithstanding that, these methods require selection of pure bacterial/fungal cultures and high molecular weight DNA. There are no permanent criteria for the interpretation of the electrophoretic pattern (in epidemiological studies). A pattern-based assay is not easily amenable to interlaboratory standardization and to the development of international databases. These methods can generate both, technical and human errors. Errors can also arise from an incomplete restriction digestion reaction due to the short time of reaction (a solution is to use Fast Digest Enzymes, Fermentas), low activity and possible star activity of enzymes or the use of methylation-sensitive enzymes. The critical parameters are the time required for ligation, the concentration of adapters in ligation reaction and activity of the DNA polymerase in PCR.

In conclusion, LM PCR methods might be very quick methods that are useful in the analysis of microbiological links. They have been used for typing closely related bacteria/yeast/dermatophytes and other microorganisms without knowledge of their nucleotide sequences. Moreover, from a technical point of view, many genomes can be analyzed in a short period of time, and only small amount of DNA is needed. In spite of the fact that reproducibility is often subjected to discussion, they may often be a good alternative tool to differentiate between highly clonal strains.

\section{REFERENCES}

Antonishyn NA, McDonald RR, Chan EL, Horsman G, Woodmansee C E, Falk PS, Mayhall CG (2000) Evaluation of fluorescence-based amplified fragment length polymorphism analysis for molecular typing in hospital epidemiology: comparison with pulsed-field gel electrophoresis for typing strains of vancomycin-resistant Enterococcus faecium. J Clin Microbiol 38: 4058-4065.

Arricau-Bouvery N, Hauck Y, Bejaoui A, Frangoulidis D, Bodier CC, Souriau A, Meyer H, Neubauer H, Rodolakis A, Vergnaud G (2006) Molecular characterization of Coxiella burnetii isolates by infrequent restriction site-PCR and MLVA typing. BMC Microbiol 6: 38.

Bachem CW, van der Hoeven RS, de Bruijn SM, Vreugdenhi D, Zabeau M, Visser RG (1996) Visualization of differential gene expression using a novel method of RNA fingerprinting based on AFLP: analysis of gene expression during potato tuber development. Plant I: $745-753$.

Bachem CW, Oomen RJFJ, Visser RGF (1998) Transcript imaging with cDNA-AFLP: A step-by-step protocol. Plant Mol Biol Rep 16: 157-173.

Ball LM, Bes MA, Theelen B, Boekhout T, Egeler RM, Kuijper EJ (2004) Significance of amplified fragment length polymorphism in identification and epidemiological examination of Candida species colonization in children undergoing allogeneic stem cell transplantation. I Clin Microbiol 42: 1673-1679.

Bensch S, Akesson M (2005) Ten years of AFLP in ecology and evolution: why so few animals? Mol Ecol 14: 2899-2914.

Bonin A Bellemain E, Bronken Eidesen P, Pompanon F, Brochmann C, Taberlet P (2004) How to track and assess genotyping errors in population genetics studies. Mol Ecol 13: 3261-3273.

Borst A, Theelen B, Reinders E, Boekhout T, Fluit AC, Savelkoul PHM (2003) Use of amplified fragment length polymorphism analysis to identify medically important Candida spp., including C. dubliniensis. J Clin Microbiol 41: 1357-1362.

Crawford LA, Koscinski D, Keyghobadi N (2012) A call for more transparent reporting of error rates: the quality of AFLP data in ecological and evolutionary research. Mol Ecol 21: 5911-5917.

Diatchenko L, Lau YF, Campbell AP, Chenchik A, Moqadam F, Huang B, Lukyanov S, Lukyanov K, Gurskaya N, Sverdlov ED, 
Siebert PD (1996) Suppression subtractive hybridization: a method for generating differentially regulated or tissue-specific cDNA probes and libraries. Proc Natl Acad Sci USA 93: 6025-6030.

Dijkshoorn L, Aucken H, Gerner-Smidt P, Janssen P, Kaufmann ME, Garaizar J, Ursing J, Pitt TL (1996) Comparison of outbreak and nonoutbreak Acinetobacter baumannii strains by genotypic and phenotypic methods. I Clin Microbiol 34: 1519-1525.

Edwards SV, Beerli P (2000) Perspective: gene divergence, population divergence, and the variance in coalescence time in phylogeographic studies. Evolution 54: 1839-1854.

Fry NK, Afshar B, Visca P, Jonas D, Duncan J, Nebuloso E, Underwood A, Harrison T G (2005) Assessment of fluorescent amplified fragment length polymorphism analysis for epidemiological genotyping of Legionella pneumophila serogroup 1. Clin Microbiol Infect 11: 704-712.

Gibson JR, Slater E, Xerry J, Tompkins DS, Owen RJ (1998) Use of an amplified-fragment length polymorphism technique to fingerprint and differentiate isolates of Helicobacter pylori. I Clin Microbiol 36: 2580-2585.

Grech K, Martinelli A, Pathirana S, Walliker D, Hunt P, Carter R (2002). Numerous, robust genetic markers for Plasmodium chabaudi by the method of amplified fragment length polymorphism. Mol Biochem Parasitol 123: 95-104.

Hartl L, Seefelder S (1998) Diversity of selected hop cultivars detected by fluorescent AFLPs. Theor Appl Genet 96: 112-116.

Huang J, Sun M (1999) A modified AFLP with fluorescence-labelled primers and automated DNA sequencer detection for efficient fingerprinting analysis in plants. Biotechnol Tech 13: 277-278.

Huang YC, Lee CY, Su LH, Chang LY, Lin TY (2005) Methicillinresistant Staphylococcus aureus bacteremia in neonatal intensive care units: genotyping analysis and case-control study. Acta Paediatr Taiwan 46: $156-160$.

Janssen P, Coopman R, Huys G (1996) Evaluation of the DNA fingerprinting method AFLP as a new tool in bacterial taxonomy. Microbiol 142: 1881-1893.

Janssen P, Maquelin K, Coopman R, Tjernberg I, Bouvet P, Kersters K, Dijkshoorn L (1997) Discrimination of Acinetobacter genomic species by AFLP fingerprinting. Int J Syst Bacteriol 47: 1179-1187.

Koeleman JG, Stoof J, Biesmans DJ, Savelkoul PH, VandenbrouckeGrauls CM (1998) Comparison of amplified ribosomal DNA restriction analysis, random amplified polymorphic DNA analysis, and amplified fragment length polymorphism fingerprinting for identification of Acinetobacter genomic species and typing of Acinetobacter baumannii. J Clin Microbiol 36: 2522-2529.

Krauss SL (1999) Complete exclusion of nonsires in an analysis of paternity in a natural plant population using amplified fragment length polymorphism (AFLP). Mol Ecol 8: 217-226.

Krawczyk B, Lewandowski K, Bronk M, Samet A, Myjak P, Kur J (2003a). Evaluation of a novel method based on amplification of DNA fragments surrounding rare restriction sites (ADSRRS fingerprinting) for typing strains of vancomycin-resistant Enterococcus faecium. I Microbiol Methods 52: 341-351.

Krawczyk B, Naumiuk L, Lewandowski K, Baraniak A, Gniadkowski M, Samet A, Kur J (2003b) Evaluation and comparison of random amplification of polymorphic DNA, pulsed-field gel electrophoresis and ADSRRS-fingerprinting for typing Serratia marcescens outbreaks. FEMS Immunol Med Microbiol 38: 241-248.

Krawczyk B, Samet A, Czarniak E, Szczapa J, Kur J (2005) Extendedspectrum beta-lactamase-producing Klebsiella pneumoniae in a neonatal unit: 1 control of an outbreak using a new ADSRRS technique. Pol J Microbiol 54: 105-110.

Krawczyk B, Samet A, Leibner J, Śledzińska A and Kur J (2006) Evaluation of a PCR Melting Profile technique for bacterial strain differentiation. J Clin Microbiol 44: 2327-2332.

Krawczyk B, Leibner J, Barańska-Rybak W, Samet A, Nowicki R, Kur J (2007a) ADSRRS-fingerprinting and PCR MP techniques for studies of intraspecies genetic relatedness in Staphylococcus aureus. I Microbiol Methods 71: 114-122.

Krawczyk B, Leibner J, Stojowska K, Bronk M, Samet A, Kur J (2007b) PCR melting profile method for genotyping analysis of vancomycin-resistant Enterococcus faecium isolates from Hematological Unit patients. Pol J Microbiol 56: 65-70.

Krawczyk B, Leibner-Ciszak J, Nowak M, Mielech A, Kur J (2009) PCR melting profile (PCR MP) - a new tool for differentiation of Candida albicans strains. BMC Infec Diseases 9: 177. doi: 10.1186/1471-2334-9-177.

Krawczyk B, Leibner-Ciszak J, Stojowska K, Kur J (2011) A new LM PCR/Shifter method for genotyping of microorganisms based on the use of class IIS restriction enzyme and ligation mediated PCR. J Microbiol Biotechnol 21: 1336-1344.

Krutkiewicz A, Klimuszko D (2010) Genotyping and PCR detection of potential virulence genes in Campylobacter jejuni and Campylobacter coli isolates from different sources in Poland. Folia Microbiol (Praha) 55: 167. doi: $10.1007 /$ s12223-010-0025-6.

Kumar A, Misra P, Dube A (2013) Amplified fragment length polymorphism: an adept technique for genome mapping, genetic differ- entiation, and intraspecific variation in protozoan parasites. Parasitol Res 112: 457. doi: 10.1007/s00436-012-3238-6.

Leibner-Ciszak, J, Dobrowolska A, Krawczyk B, Kaszuba A, Stączek P (2010) Evaluation of PCR MP method for intra-species differentiation of Trichophyton rubrum and Trichophyton interdigitale. I Med Microbiol 59: 185-192.

Martinelli A, Hunt P, Fawcett R, Cravo PV, Walliker D, Carter R (2005) An AFLP-based genetic linkage map of Plasmodium chabaudi chabaudi. Malar J 4: 11. doi: 10.1186/1475-2875-4-11.

Masny A, Plucienniczak A (2001) Fingerprinting of bacterial genomes by amplifcation of DNA fragments surrounding rare restriction sites. BioTechniques 31: 930-936.

Masny A, Płucienniczak A (2003) Ligation-mediated PCR performed at low denaturation temperatures-PCR melting profiles. Nucl Acids Res 31: 114.

Mazurek GH, Reddy V, Marston BJ, Haas WH, Crawford JT (1996) DNA fingerprinting by infrequent-restriction-site amplification. J Clin Microbiol 34: 2386-2390.

Mueller UG and Wolfenbarger LL (1999) AFLP genotyping and fingerprinting. Trends Ecol Evol 14: 389-394.

Palittapongarnpim P, Chomyc S, Fanning A, Knimoto D (1993) DNA fingerprinting of Mycobacterium tuberculosis isolates by ligation-mediated polymerase chain reaction. Nucleic Acids Res. 21:761-762.

Prod'hom G, Guilhot C, Gutierrez MC, Varnerot A, Gicquel B, Vincent V (1997) Rapid discrimination of Mycobacterium tuberculosis complex strains by ligation-mediated PCR fingerprint analysis. J Clin $\mathrm{Mi}$ crobiol. 35: 3331-3334.

Reisig F, Kremer K, Amthor B, van Soolingen D, Haas WH (2005) Fast ligation-mediated PCR, a fast and reliable method for IS6110based typing of Mycobacterium tuberculosis complex. J Clin Microbiol 43: 5622-5627.

Riffard S, Lo Presti F, Vandenesch F, Forey F, Reyrolle M, Etienne J (1998) Comparative analysis of infrequent-restriction-site PCR and pulsed-field gel electrophoresis for epidemiological typing of Legionella pneumophila serogroup 1 strains. J Clin Microbiol 36: 161-167.

Salmon A, Ainouche ML, Wendel JF (2005) Genetic and epigenetic consequences of recent hybridization and polyploidy in Spartina (Poaceae). Mol Ecol 14: 1163-1175.

Stefańska I, Rzewuska M, Binek M (2008) Evaluation of three methods for DNA fingerprinting of Corynebacterium pseudotuberculosis strains isolated from goats in Poland. Pol. J. Microbiol 57: 105-12.

Stojowska K, Krawczyk B, Kałużewski S, Kur J (2009a) Retrospective analysis of genetic diversity of Klebsiella oxytoca isolated in Poland over a 50-year period. Eur J Clin Microbiol Infect Dis 28: 1263. doi: 10.1007/s10096-009-0768-7.

Stojowska K, Krawczyk B, Kałużewski S (2009b) Usefulness of PCR melting profile method for genotyping analysis of Klebsiella oxytoca isolates from patients of a single hospital unit. Pol J Microbiol 58: 247-253.

Stojowska K, Krawczyk B (2014) A new double digestion ligation mediated suppression PCR method for simultaneous bacteria DNAtyping and confirmation of species: an Acinetobacter sp. model. PLoS One 9: 115181. doi: 10.1371/journal.pone.0115181.

Su LH, Leu HS, Chiu YP, Chia JH, Kuo AJ, Sun CF, Lin TY, Wu TL (2000) Molecular investigation of two clusters of hospital-acquired bacteraemia caused by multi-resistant Klebsiella pneumoniae using pulsed-field gel electrophoresis and in frequent restriction site PCR. Infection Control Group. J Hosp Infect 46: 110-117.

Sunnucks P (2000) Efficient genetic markers for population biology. Trends Ecol Evol 15: 199-203.

Tavanti A, Hensgens LAM, Ghelardi E, Campa M, Senesi S (2007) Genotyping of Candida orthopsilosis clinical isolates by amplification fragment length polymorphism reveals genetic diversity among independent isolates and strain maintenance within patients. I Clin Microbiol 45: 1455-1462.

Xu M, Li X, Korban SS (2004) DNA-methylation alterations and exchanges during in vitro cellular differentiation in rose (Rosa bybrida L.). Theor Appl Genet 109: 899-910.

Yoo JH, Choi JH, Shin WS, Huh DH, Cho YK, Kim KM, Kim MY, Kang MW (1999) Application of infrequent-restriction-site PCR to clinical isolates of Acinetobacter baumannii and Serratia marcescens. J Clin Microbiol 37: 3108-3112.

Vekemans X, Beauwens T, Lemaire M, Roldán-Ruiz I (2002) Data from amplified fragment length polymorphism (AFLP) markers show indication of size homoplasy and of a relationship between degree of homoplasy and fragment size. Mol Ecol 11: 139-151.

Vos P, Hogers R, Bleeker M, Reijans M, van de Lee T, Hornes M, Frijters A, Pot J, Peleman J, Kuiper M, Zabeau M (1995) AFLP: a new technique for DNA fingerprinting. Nucleic Acids Res 23: 4407-4414.

Woksepp H, Jernberg C, Tärnberg M, Ryberg A, Brolund A, Nordvall $M$, Olsson-Liljequist $B$, Wisell $K T$, Monstein $H J$, Nilsson LE, Schön T (2011) High-Resolution melting-curve analysis of LigationMediated Real-Time PCR for rapid evaluation of an epidemiological outbreak of extended-spectrum-Beta-lactamase-producing Escherichia coli. J Clin Microbiol 49: 4032-4039. 
van der Wurff AWG, Chan YL, van Straalen NM, Schouten J (2000) TE-AFLP: combining rapidity and robustness in DNA fingerprinting. Nucleic Acids Res 28: 105.

Zaczek A, Brzostek A, Górna A, Sajduda A, Wojtasik A, Dziadek J (2013) Application of FLiP method for differentiation of Mycobacterium tuberculosis strains in comparison to commonly used methods, spoligotyping and MIRU-VNTR typing. Pol J Microbiol 62: 73-76.

Zaczek A, Brzostek A, Kuroń A, Wojtasik A, Sajduda A, Dziadek J (2014) Development of a new ligation-mediated PCR method for the differentiation of Mycobacterium tuberculosis strains. Int J Tuberc Lung Dis 18: 302-309. doi: 10.5588/ijtld.13.0538.
Zaczek A, Woitasik A, Izdebski R, Gorecka E, Wojcik EA, Nowak T, Kwiecinski P, Dziadek J (2015) PCR melting profile as a tool for outbreak studies of Salmonella enterica in chickens. BMC Vet Res. 11: 137. doi: 10.1186/s12917-015-0451-4.

Zasada AA, Forminska K, Wołkowicz T, Badell E, Guiso N (2014) The utility of the PCR melting profile technique for typing Corynebacterium diphtheriae isolates. Letters Appl Microbiol 59: 292. doi: 10.1111/lam.12274. 